\title{
NOVELTIES IN SECURITY MEASURES - THE EXTENDED SEIZURE
}

\author{
N. E. Buzatu, A. Uzlău
}

\begin{abstract}
Nicoleta-Elena Buzatu
Faculty of Juridical and Administrative Sciences

"Dimitrie Cantemir" Christian University, Bucharest, Romania

*Correspondence: Nicoleta-Elena Buzatu, "Dimitrie Cantemir" Christian University, 176

Splaiul Unirii, 4 District, Bucharest, Romania

E-mail: nicoleta_buzatu@yahoo.com
\end{abstract}

\section{Andreea Uzlău}

Faculty of Juridical and Administrative Sciences

"Dimitrie Cantemir" Christian University, Bucharest, Romania

*Correspondence: Andreea Uzlău, "Dimitrie Cantemir" Christian University, 176

Splaiul Unirii, 4 District, Bucharest, Romania

E-mail: stoicaandreea76@yahoo.com

\begin{abstract}
This work analyses the recent regulation, which amends the current and the future Criminal Code, in the sense of establishing, as a new security measure, the extended seizure. Analyzing the provisions of the regulation, the authors indicates, the necessity to amend the Criminal Procedure Code is underlined, with the purpose of ensuring the regulation operability within the criminal proceedings.
\end{abstract}

\section{Keywords: extended seizure, licit property acquisition presumption, Security Measures, New Criminal Code}

\section{Introduction}

Extended seizure is forced and free passage in State ownership of certain things, which belong to the person who has committed a crime, because of their origin from the criminal activities of the same nature, carried out by that person, constantly, over a certain period of time, prior to the offence for which the person is sentenced.

Extended seizure is a criminal sanction, which is personal and irrevocably.

A recent regulation adopted by the Romanian Parliament ${ }^{1}$, amends the Criminal Code ${ }^{2}$ in force, by introducing a new article art. $118^{1}$, with marginal noun as "extended seizure", and the new Criminal Code, adopted by law No. $286 / 2009^{3}$, which will enter into force on the date set by law enforcement, by introducing a new article $-118^{2}$ with the same marginal name. The provisions that will change the new Criminal Code will take effect with it.

\footnotetext{
${ }^{1}$ Law No. 63/2012, published in the Official Gazette of Romania, part I, no. 258 of 19 April 2012.

${ }^{2}$ Law No. 15 of 21 June 1968 - The Criminal Code of Romania, published in the Official Gazette of Romania nr. 79-79 Bis of 21 June 1968, republished in the Official Gazette of Romania No. 55-56 of 23 April 1973 and then in the Official Gazette of Romania, part I, No. 65 of 16 April 1997.

${ }^{3}$ Law No. 286 of 17 July 2009 - The Criminal Code of Romania, published in the Official Gazette of Romania, part I, No. 510 of 24 July 2009.
} 
The reason for issuing this law is, as shown by the initiator ${ }^{4}$, the transposing of article 3 of Council framework decision nr. 2005/212/JHA ${ }^{5}$ on confiscation of products, tools and other items related to crime.

According to par. (10) in the preamble to framework decision, its aim is to ensure that all Member States have effective rules governing the seizure of the products related to crime, inter alia, relating to the burden of proof regarding the source of assets held by a person convicted of an offence related to organized crime.

Article 3 of the framework decision confers increased powers of seizure to Member States, for goods resulting from criminal activities, carried out by the person sentenced or where it is established that the value of goods held is disproportionate in relation to the convicted person's legal income.

Thus, although currently Romania shall benefit from a coherent and comprehensive legal framework, developed in line with international standards in the matter of the seizure of criminal products, the framework has some shortcomings with regard to European requirements.

At the level of national legislation, the Council framework decision mentioned above was not entirely transposed. The transposition of art. 3 on the extended seizure was missing.

The measure must allow the seizure of property derived from criminal activities which are not directly linked to the offence for which the person is condemned. The direct connection between the offence giving rise to the conviction and assets that are seized is not proven, therefore. This is the so-called principle of extended seizure of the goods.

The analyzed framework decision is not for general, but covers a specific situation, namely that of preventing and combating organized cross-border crime, for the purpose of detection, freezing, seizing and confiscation of products relating to the offence. The regulation therefore starts from a premise, namely that of the existence of a conviction.

The acquisition of the extended seizure under national law requires the regulation of the express limited cases, in which the constant conduct of serious criminal activities by a person, over a certain period of time, combined with the absence of other regular income, it is considered a sufficient evidence to enable the Court to establish that the goods were illegally acquired. A new view of the burden of proof in matters relating to the acquisition of illicit property is established.

The existing legislation at national level may not derogate from the basic principles laid down in the European Convention on human rights and from the rule established in article 1 of additional Protocol 1, entitled "Protection of property".

In the same connection, the article 5 of the framework decision 2005/212 may be invoked, according to which the provisions of the latter shall not have the effect of modifying the obligation to respect fundamental rights and fundamental principles, including the presumption of innocence, as enshrined in article 6 of the Treaty on European Union.

The lack of implementation, thus far, of the normative instrument of the European Union was due, in good measure, to the controversy related to the compliance of this regulation with the constitutional principle referred to in paragraph 1 (8) article 44 of the Constitution ${ }^{6}$.

Operating exclusively in criminal proceedings, for a list of particularly serious offences and applying exclusively to a person already convicted, the extended seizure is not incompatible with the presumption of lawful acquisition of property.

\footnotetext{
${ }^{4}$ The explanatory memorandum, available on the website www.just.ro.

${ }^{5}$ Council Framework Decision 2005/212/JHA of 24 February 2005 on Confiscation of Crime-Related Proceeds, Instrumentalities and Property, published in the Official Journal of the European Union L Series No. 68 from 15 March 2005.

6 The Romanian Constitution, as amended by the law of the revision of the Constitution of Romania No. 429/2003, published in the Official Gazette of Romania, part I, no. 758 of 29 October 2003, republished in the Official Gazette of Romania, part I, no. 764 of 31 October 2003.
} 


\section{N. E. Buzatu, A. Uzlău}

This presumption is relative, so it will be down, on a case-by-case basis, through the provision of evidence convincing the Court that the property held by the sentenced person are obtained from committing crimes.

The Prosecutor would thus be obliged to prove that one particular person, over a period of time, has been involved in committing certain crimes, such as acts of organized crime. Since that time, the judge can reasonably assume that the assets acquired are the result of criminal activities carried out by the sentenced person, for a period prior to conviction that is considered reasonable by the Court. In this case, the burden of proof on the licit acquisition of the goods is the responsibility of the convicted person. If the judge concludes that the value of the held goods is disproportionate in relation to the legal revenue, he may require their confiscation from the convicted person.

The Constitutional Court has indicated in the same sense by decision no. 799 of 17 June 2011, on the draft law on revision of the Constitution, noting that the presumption of lawful acquisition of property does not prevent the legislature, pursuant to art. 148 of the Constitution - The integration in the European Union - to adopt regulations to allow full compliance with the legislation of the Union in the fight against organized crime.

In this context, in relation to the provisions of art. 44 par. (9) of the Constitution of Romania, republished, which stipulates that "goods destined for, used or resulted from crimes or offences may be confiscated only under the law", we appreciate that because the extended seizure operates exclusively in criminal proceedings, aims at a series of serious offences and shall apply exclusively to a person already convicted - introduction of such proceedings is not incompatible with the presumption of licit nature of property, ranging from art. 44 par. (8) of the Constitution of Romania, republished.

2. Conditions for taking the extended seizure measure

a. Extended Confiscation may be ordered against a person who has committed a criminal offence prescribed by the law, but also against members of the families of the persons with whom it has established relations similar to those of spouses or between parents and children, if they are living together, or legal entities to which the sentenced person has control.

In this regard, it should be noted that the meaning of the expression "member of the family" in the new criminal Code differs from the meaning of the Penal Code in force. Thus, according to art. $149^{1}$ Criminal Code: "member of the family means spouse or close relative, if the latter lives and work together with the perpetrator."

Art. 177 of Law No. 286/2009 concerning the Criminal Code provides:

"(1) member of the family means:

a) ascendants and descendants, brothers and sisters, their children, and persons rendered through adoption, according to the law, such relatives;

b) husband;

c) persons which have established relationships similar to those of spouses or between parents and children, if they are living together.

(2) the provisions of criminal law concerning family member, within the limits laid down in paragraph 1. (1) letter a), shall apply, in cases of adoption, and the person adopted or its descendants in relation to the natural relatives".

Analyzing the laws pre-quoted, whereas the new Criminal Code enlarges the scope of persons treated as family member, in respect of the current Criminal Code was necessary to introduce a specific provision in the sense that, in the rules in force, extended confiscation applies to persons who have established relationships similar to those of spouses or between parents and children, if they are living together with the sentenced person.

b. Extent of safety is taken if there is the certitude that the person sentenced has conducted criminal activities other than those for which he was convicted, but of a similar nature. 
Under this aspect, as the initiator, the regulation provide that the measure of safety applicable to all offences for which the law provides for a prison sentence of more than five years, limit referring both to the current and the new Criminal Code.

Under parliamentary procedure, it was noted that the scope of the measure must be restricted, by the provision of double-glazed conditionings. On the one hand, there have been specified categories of serious crimes for which extended seizure can be incident: human trafficking; offences relating to the traffic of drugs and precursors; crimes at the border of Romania; money laundering; infractions of the law on prevention and combat of pornography; crimes of terrorism; association for committing offences; the crime of initiation or setting up an organized criminal group or join or support any form of such a group; offences against property; offences relating to the regime of weapons, munitions, explosive materials, radioactive, nuclear; the counterfeiting of currency or other values; disclosure of secrets, unfair competition, breach of provisions relating to the import or export operations, embezzlement, breach of provisions relating to the import of wastes and residues; offences relating to gambling; trafficking in migrants; corruption offences, offences similar crimes of corruption, offences related to corruption offences, offences against the financial interests of the European Union; tax avoidance; offences relating to the customs procedure; offences committed by means of computer systems and electronic means of payment; trafficking in human organs or tissues. In relation to the new Criminal Code, the list of crimes was adapted accordingly.

On the other hand, it was intended that the penalty prescribed by law for the offence committed is imprisonment for five years or longer (i.e. imprisonment of 4 years or more in the new Criminal Code).

This regulation is, in our opinion, in line with the European regulatory action which it implements, which does not have a general, but aims at a specific situation, namely that of preventing and combating organized cross-border crime. In this regard, the provisions of art. 3 of Council framework decision nr. 2005/212/JHA shall list the categories of crimes which require regulation increased confiscation powers for the Member States, making, for example, referring to offences relating to combating trafficking in persons, combating the sexual exploitation of children and child pornography, illicit drug trafficking and other serious crimes committed in the wider criminal organizations.

c. the value of assets acquired by the person convicted, within a period of five years before and, if necessary, after the committal of the crime until the date of issue of the document instituting the proceedings, obviously exceeds the licit revenues.

Application of the measure means, therefore, setting a time interval that begins with five years before the date of the offence for which he has ordered the conviction and ending on the date of issue of the indictment. In the case of the offence continued, we appreciate that the time of 5 years shall be calculated from the date of the last act of execution, which is the date of exhaustion of criminal activity.

According to this period, will be analyzed the total amount of regular income gained by the person convicted and the difference between this amount and the total of assets acquired during the same period, in order to determine whether there is a obvious disproportion.

Property of movable or immovable property will be considered, including monies, acquired by the person convicted in his own name, the property transferred by it or by a third party of a member of the family, the person sentenced has established relationships similar to those of spouses or between parents and children, if they are living together with him, to legal persons on which the sentenced person has control well as expenditure incurred within the reference to the categories of persons mentioned.

\section{Conclusions and suggestions de lege ferenda}




\section{N. E. Buzatu, A. Uzlău}

The new provisions concerning the extent of security of extended seizure are likely to ensure at the same time the guarantee of legal reports security and the implementation of the obligations imposed by the Romanian legal norms binding the community. The settlement can be improved in several aspects.

Thus, with regard to the acquisition of goods within a period of five years prior to the committal of the crime, if there are reasonable indications as to the timing of the crime, it is not justified to extend beyond this period the seizure. If, however, the Court has reasonable evidence that the criminal activity of the nature of the crime that attracted the condemnation took place over a period of more than 5 years, is not the limitation in time, having taken into account all the period of criminal activity.

On the other hand, if his criminal activity cannot be established, but there is no indication that the person has received proceeds from criminal activities, the period of 5 years is justified.

With regard to the calculation of the reference range, we appreciate that time reporting should have regard to the moment of final decision of condemnation, with the limitations imposed by the principle of non reformatio in pejus.

Thus, there are times when even in the period between the time of sending to trial and the final decision, the sentenced person may acquire property through the use of income from activities of a kind that drew condemnation.

As regards the categories of persons whose assets may be covered by special seizure, we consider insufficient regulation, because, although it provides that an assessment of the illicit character of goods other than those referred to in art. 118 of the Criminal Code, account shall be taken of the value of goods transferred by the person convicted or by a third party to a family member or a legal person on whom the accused/defendant has control, from the contents of the draft normative act is not clear whether the measure can be ordered and seizure from persons concerned.

Therefore, after paragraph 2 of art. $118^{2}$ should introduce a new paragraph, within the meaning of the provision expressly to the possibility of extended seizure and disposition of action against persons presumed by law to be intermediate, someone as a family member or a legal person of which the sentenced person has control, of course with the fulfillment of conditions stemming from regulatory action: derives from the nature of the activities which have attracted condemnation by default and should not be purchased in regular income.

This legislative solution was chosen also in the case of goods which have been used in any way, to commit an offence, if they belong to another person, if the person concerned has the purpose to be used - art. 118. 1 lit. b of the Criminal Code.

The express provision of possible confiscation of property that is located in the heritage of persons presumed by law to be intermediate, would open the way for protective measures against property belonging to them. In this regard, to the extent that the safety of extended seizure is not rendered devoid of content and thus to transform itself to an extent illusory, by the alienation of property covered by the confiscation, it is necessary, in addition to completing properly the provisions of art. 163 of the Code of Criminal Procedure and article 249 par. 1 of Law No. 135/2010 on the New Code of Criminal Procedure with the provision that protective measures are taken and expanded with a view to confiscation, also to provide the possibility of disposing of such measures against persons presumed by law to be intermediate.

De lege lata, protective measures may be taken only in respect of the accused/defendant or person responsible in the perspective of Civil Law.

Legislative intervention should be required more as the Law no. 135/2010 - New Code of Criminal Procedure provides in art. 249 par. 3 protective measures for special seizure and to ensure execution of criminal fine "can be taken only in respect of the suspect or the accused". 
At the same time, to be able to implement the new regulations is necessary to achieve other amendments to the Criminal Procedure $\operatorname{Code}^{7}$ and the provisions of Law No. 135/2010 - New Code of Criminal Procedure ${ }^{8}$. Thus, taking into account new powers of investigation conferred to judicial bodies (the prosecution and courts) in respect of the identification of other goods than those mentioned in art. 118 of the Criminal Code in patrimony or heritage of the sentenced person or a family member or legal persons on which the person sentenced has control, in procedure should be made a number of additions that allow the organs of the judicial to check everything mentioned above.

Thus, the contents of articles 202 and 287 of the Code of criminal procedure, which regulates the role of the criminal investigation body, namely the role of the Court, could be expanded through the imposition of an obligation borne by the criminal prosecution authorities and the courts to collect data relating to the accused/defendant or a member of his family or legal entity over which it has control of other goods than those mentioned in art. 118 of the Criminal Code.

At the same time, we appreciate that the introduction of a transitional provisions concerning exemption cases pending judgment from the application of the measure would have been required.

The main arguments that can substantiate such regulations are as follows:

a. significant difficulties for the administration of evidence, necessary for the application of the extended seizure to cases already in the course of the trial; the identification, with specific procedural means, of the goods subject to verification (of the accused, the members of his family, with which he has established relations similar to those of spouses or between parents and children, of the legal persons on which the defendant has control) involves checks at all Bank units at land register offices, financial administrations, etc.

Given the complexity of such checks, is reportedly a significant increase of the duration of cases in the trial phase.

b. the compliance with the relevant case-law of the European Court of human rights

The extended seizure, by its extent and severity, constitutes a punishment within the meaning of the case law of the European Court of human rights (case of Engel v. the Netherlands, Judgment of 8 June 1976), so it should enjoy all procedural guarantees required by the European Convention of human rights and fundamental freedoms (hereinafter referred to as the Convention) in the case of a criminal trial.

Thus, in the absence of a text excluding cases pending judgment in applying the extended seizure, this measure will come into conflict with the Convention and also will generate a non uniform jurisprudence.

Thus, the measure is applicable to causes in the appeal phase, which will lead to the application of a punishment without granting an appeal against it; this situation is contrary to art. 2 of Protocol 7 to the Convention, on the double degree of jurisdiction in criminal matters;

Also, according to art. 12 par. (2) of the actual Criminal Code, "the law which provides for safeguard measures or educational measures are applied to the crimes which have not been definitively judged until the date of entry into force of the new law."

It appears that the courts should make the application of the extended seizure to cases pending trial. However, interpreting these provisions in the light of the Convention, dealing with the institution in its essence, the Court may take into account the principle of the

\footnotetext{
${ }^{7}$ Law No. 29 of November 12, 1968 - The Criminal Procedure Code of Romania, published in the Official Gazette of Romania nr. 145 of 12 November 1968, republished in the Official Gazette of Romania, Part I, no. 78 of 30 April 1997, as amended.

${ }^{8}$ Law No. 135 of July 1, 2010 - the Criminal Procedure Code of Romania, published in the Official Gazette of Romania, Part I, no. 486 of 15 July 2010. This code comes into force on the date which will be fixed by the implementing law.
} 


\section{N. E. Buzatu, A. Uzlău}

application of the Criminal Law more favorable. Accordingly, the courts will not apply this measure cases pending judgment.

Therefore, the lack of an explicit text creates the risk of a non uniform jurisprudence.

Furthermore, for the same reasons, related to the principle of the application of the Criminal Law more favorable, the new Criminal Code no longer retain the solution governed by article 12 par. (2) of the actual Criminal Code.

\section{Bibliography}

Law No. 63/2012, published in the Official Gazette of Romania of Romania, part I, no. 258 of 19 April 2012.

Law No. 286 of 17 July 2009 - The Criminal Code of Romania, published in the Official Gazette of Romania, part I, No. 510 of 24 July 2009.

Law No. 135 of July 1, 2010 - The Criminal Procedure Code of Romania, published in the Official Gazette of Romania, part I, no. 486 of 15 July 2010. This Code comes into force on the date which will be fixed by the implementing law.

Council Framework Decision 2005/212/JHA of 24 February 2005 on Confiscation of Crime-Related Proceeds, Instrumentalities and Property, published in the Official Journal of the European Union L Series No. 68 from 15 March 2005.

The Romanian Constitution, as amended by the law of the revision of the Constitution of Romania No. 429/2003, published in the Official Gazette of Romania of Romania, part I, no. 758 of 29 October 2003, republished in the Official Gazette of Romania of Romania, part I, no. 764 of 31 October 2003.

Law No. 15 of 21 June 1968 - The Criminal Code of Romania, published in the Official Gazette of Romania nr. 79-79 Bis of 21 June 1968, republished in the Official Gazette of Romania No. 55-56 of 23 April 1973 and then in the Official Gazette of Romania, part I, No. 65 of 16 April 1997.

Law No. 29 of November 12, 1968, The Criminal Procedure Code of Romania, published in the Official Gazette of Romania nr. 145 of 12 November 1968, republished in the Official Gazette of Romania, part I, no. 78 of 30 April 1997, as amended.

The Explanatory Memorandum, available on the website www.just.ro. 